\title{
SISTEM INFORMASI PENGELOLAAN KEUANGAN PADA PRIMAZ TOUR \& TRAVEL SAMARINDA BERBASIS LOCAL AREA NETWORK (LAN)
}

\author{
M. Irwan Ukkas ${ }^{1)}$, Amelia Yusnita ${ }^{2)}$, Astuty Nilasari ${ }^{3)}$ \\ ${ }^{1,2}$ Sistem Informasi, Stmik Widya Cipta Dharma \\ ${ }^{3}$ Sistem Informasi, Stmik Widya Cipta Dharma \\ 1,2,3 J1. Prof. M. Yamin No. 25, Samarinda, 75123 \\ E-mail : Irwan212@yahoo.com ${ }^{1)}$, qonita23@yahoo.com ${ }^{2)}$,informatikawicida@gmail.com ${ }^{3)}$
}

\begin{abstract}
ABSTRAK
Primaz Tour \& Travel Samarinda yang merupakan perusahaan jasa penjualan tiket pesawat terbang dan agen perjalanan. Sampai saat ini masalah sistem informasi pengelolaan keuangan yang dihadapi perusahaan ini bahwa produk akhir dari mutasi rekening penjualan tiket masih menggunakan cara manual dan menggunakan perangkat komputer dengan pengolahan data laporan menggunakan aplikasi Ms. Excel.

Metode yang digunakan dalam penelitian ini meliputi metode pengumpulan data yaitu penelitian lapangan dan penelitian kepustakaan. Sedangkan metode pengembangan sistem yang digunakan dalam pengembangan sistem informasi ini adalah metode waterfall terdiri dari perencanaan sistem, analisis sistem, desain sistem, penerapan sistem, dan perawatan sistem. Sistem ini dikembangkan dengan pemrograman Microsoft Visual Basic 6.0 dan databasenya dibangun dengan menggunakan $M y S Q L$, karena kebutuhan yang selalu berkembang, maka kekurangan pada sistem ini nantinya dapat diperbaiki pada pengembangan sistem selanjutnya. Dengan bantuan tool seperti Flow Of Document (FOD), Data Flow Document (DFD), Hierarchy Input Process Output (HIPO), Struktur Database dan Desain Input Output Program.

Penelitian ini menghasilkan Sistem Informasi Pengelolaan Keuangan Pada Primaz Tour \& Travel Berbasis Local Area Network (LAN) yang dapat diakses oleh bagian Adminstrasi, bagian Bendahara dan Pimpinan. Aktivitas yang dapat dilakukan dengan sistem ini meliputi input data penjualan, proses laporan penjualan, melengkapi data penjualan, pembelian, biaya, mencetak laporan keuangan (pendapatan dan biaya atau R/L).
\end{abstract}

Kata Kunci : Sistem, Informasi, Pengelolaan Keuangan, dan Local Area Network (LAN)

\section{PENDAHULUAN}

Dewasa ini perkembangan teknologi informasi sudah sedemikian pesat. Pemanfaatan komputer sebagai alat kerja bantu manusia, khususnya sebagai media pengolah data, baik yang berskala besar maupun kecil, sekarang ini mengalami perkembangan positif yang sangat pesat. Hal ini didukung oleh faktor pendorong dan faktor keunggulan dari komputer itu sendiri. Faktor pendorong dapat berupa kemajuan teknologi di bidang informasi, serta kebutuhan dan tuntutan manusia yang menginginkan semua pekerjaan dan kebutuhannya dapat dilaksanakan dengan cepat dan akurat.

Banyak hal yang menjadi motivasi sebuah perusahaan untuk berkembang dan banyak hal pula yang dibutuhkan untuk mendukung terhadap motivasi tersebut. Dalam dunia usaha sekarang ini komputer bukan lagi teknologi yang harus digunakan, apalagi dalam setiap aktifitas keseharian komputer adalah kebutuhan utama dari sebuah perusahaan.

Primaz Tour \& Travel Samarinda merupakan salah satu badan usaha yang bergerak di bidang penjualan tiket pesawat terbang, kereta api secara online dan rental mobil. Penggunaan komputer diharapkan dapat membantu Primaz Tour \& Travel Samarinda untuk dapat menyelesaikan suatu pekerjaan dengan cepat dan tepat, salah satunya adalah permasalahan pengelolaan keuangan dari hasil penjualan tiket pesawat udara, tiket kereta api, rental mobil dan pendapatan dari sub agen dicatat secara manual dan sering terjadi kekeliruan. Pencatatan diperlukan agar dapat memantau posisi keuangan secara periodik pada Primaz Tour \& Travel Samarinda. Karena masih dikerjakan secara manual, maka dari itu penggunaan komputer dirasakan sangat dibutuhkan dalam menyelesaikan permasalahan yang ada.

Dari latar belakang masalah tersebut, maka untuk membantu menyelesaikan masalah, perlu dibantu dibuatlah suatu Sistem Informasi Pengelolaan Keuangan Berbasis Local Area Network (LAN) dengan tujuan dapat memberikan informasi yang akurat kepada beberapa bagian yang membutuhkan informasi tersebut. 


\section{RUANG LINGKUP PENELITIAN}

Dalam penelitian ini permasalahan mencakup :

\section{Cakupan Masalah}

Terdapat beberapa kendala dalam hal pengelolaan data laporan keuangan pada Primaz Tour \& Travel seperti kesulitan dalam mendapatkan laporan penjualan, laporan pengeluaran biaya, dan laporan laba/rugi. Karena laporan tersebut dikerjakan secara terpisah, dan tidak terhubung antar computer. Hal tersebut membuat Pimpinan membutuhkan waktu yang lama untuk dapat mengetahui posisi keuangan perusahaan. Dan kesulitan tersebut membuat pekerjaan menjadi tidak hemat waktu.

2. Batasan-batasan penelitian

1.Bagian Administrasi (Front Office)

Bagian Front office memliliki hak akses yaitu meliputi penginputan data pendapatan/penjualan dan data biaya dan pembelian

2.Bendahara:

Untuk membuat proses laporan keuangan, Bendahara memiliki hak akses yang terdiri dari Master Pendapatan, Master Biaya dan Perhitungan Laba/Rugi

3. Pimpinan (Head Office)

Pimpinan sebagai pihak yang membutuhkan memliki hak akses untuk semua laporan baik Laporan Pendapatan, Laporan Biaya dan Laporan Rugi/Laba

3. Rencana hasil yang didapatkan

1. Untuk membangun suatu Sistem Informasi Pengelolaan Keuangan Berbasis Local Area Network (LAN) yang dimana suatu sistem tersebut dapat digunakan oleh front office demi kelancaran dalam kinerja.

2. Mempermudah Bendahara dalam membuat proses laporan keuangan peruasahaan travel.

3. Mempermudah Pimpinan dalam mendapatkan data laporan keuangan dengan cepat dan akurat.

\section{BAHAN DAN METODE}

\subsection{Penjelasan Bahan}

Sitem menurut Scott(2002), adalah sekelompok elemen-elemen yang saling terintegrasi dengan maksud untuk mencapai tujuan

MySQL tergolong sebagai DBMS (Database Management System). Perangkat lunak ini bermanfaat untuk mengelola data dengan cara yang sangat fleksibel dan cepat. (Kadir, 2009)

Visual Basic selain disebut sebagai bahasa pemrograman (Language Program), juga sering disebut sebagai sarana (Tool) untuk menghasilkan programprogram aplikasi berbasis Windows. (Yuswanto, 2003) proyek-proyek pengembangan perangkat lunak (Simarmata, 2010).

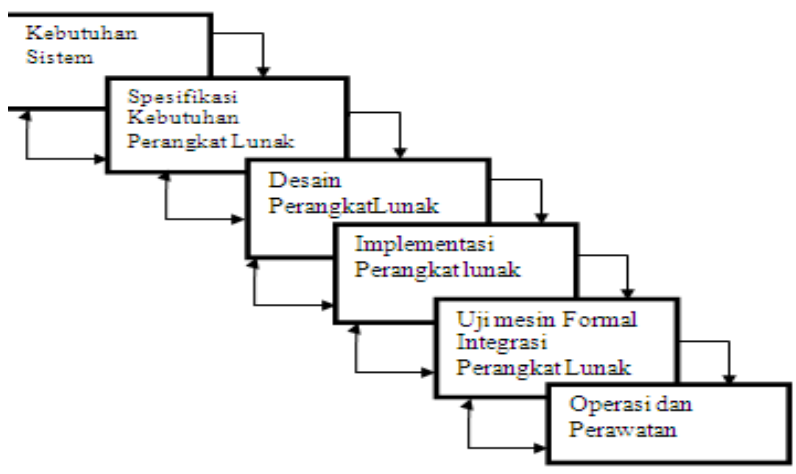

Gambar 1. Model Pengembangan Air Terjun

\section{RANCANGAN SISTEM/APLIKASI}

Berikut adalah rancangan sistem yang berjalan :

\section{Flow Of Document (FOD) Yang Berjalan}

Pada Flow Of Document sistem yang sedang berjalan tersebut, dijelaskan bahwa bagian keuangan atau bendahara memberian data jenis pendapatan untuk dilakukan proses pendataan jenis pendapatan dan menghasilkan data master pendapatan. Bagian keuangan atau bendahara memberian data jenis biaya untuk dilakukan proses pendataan jenis biaya dan menghasilkan data master biaya.

Front Office memberikan data penjualan ke bagian keuangan atau bendahara, lalu dilakukan proses pendataan pendapatan dan menghasilkan daftar pendapatan. Bagian administrasi memberikan data biaya ke bagian keuangan atau bendahara, lalu dilakukan proses pendataan biaya dan menghasilkan daftar biaya. Dari master pendapatan, master biaya, daftar pendapatan dan daftar biaya kemudian dilakukan proses perhitungan rugi/laba dan menghasilkan data rugi/laba.

Dari semua data tersebut kemudian dilakukan proses pembuatan laporan. Laporan yang dihasilkan yaitu laporan daftar pendapatan, laporan daftar biaya, laporan pendapatan, laporan biaya dan laporan laba rugi. Laporan-laporan tersebut kemudian diberikan kepada pimpinan untuk diperiksa dan disetujui. Laporan yang sudah disetujui diarsipkan oleh pimpinan dan rangkap duanya diberikan lagi kepada bagian keuangan atau bendahara.

\subsection{Metode}

Model Air Terjun (Waterfall) adalah untuk membantu mengatasi kerumitan yang terjadi akibat 


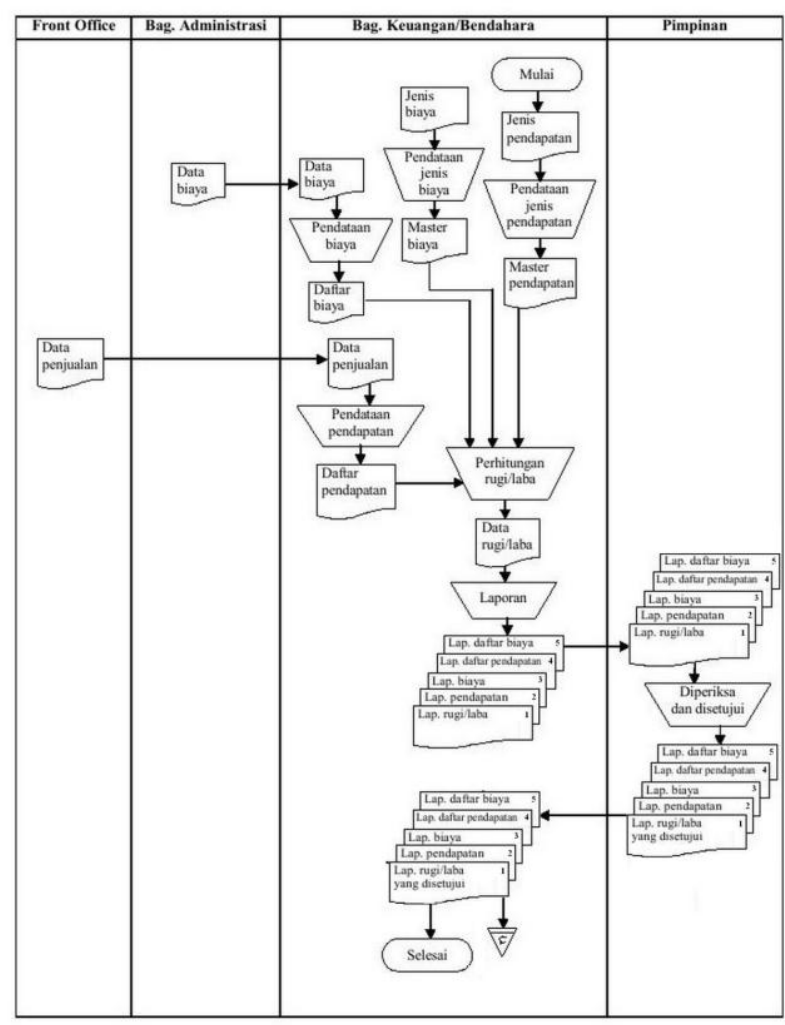

Gambar 2. FOD Yang Berjalan

\section{Flow Of Document (FOD) Yang Diusulkan}

Pada Flow Of Document sistem yang sedang diusulkan tersebut, dijelaskan bahwa Bagian adminstrasi memberikan data jenis pendapatan untuk dilakukan proses pendataan jenis pendapatan dan hasilnya disimpan di master pendapatan. Bagian adminstrasi memberikan data jenis biaya untuk dilakukan proses pendataan jenis biaya dan hasilnya disimpan di master biaya.

Front Office memberikan data penjualan ke bagian keuangan atau bendahara. Data penjualan tersebut kemudian dimasukan dalam proses pendataan pendapatan dan hasilnya disimpan di master pendapatan yang ada di server Bagian keuangan atau bendahara. Bagian administrasi memberikan data biaya untuk dilakukan proses pendataan biaya dan hasilnya disimpan di master biaya yang ada di server bagian keuangan atau bendahara. Dari master pendapatan dan master biaya kemudian dilakukan proses perhitungan rugi/laba dan hasilnya disimpan di master rugi/laba.

Dari semua data tersebut kemudian dilakukan proses pembuatan laporan. laporan yang dihasilkan yaitu laporan daftar pendapatan, laporan daftar biaya, laporan pendapatan, laporan biaya dan laporan rugi/laba. Laporan-laporan tersebut kemudian diberikan kepada Pimpinan untuk diperiksa dan disetujui. Laporan yang sudah disetujui diarsipkan oleh Pimpinan dan rangkap duanya diberikan lagi kepada Bagian Keuangan atau Bendahara.

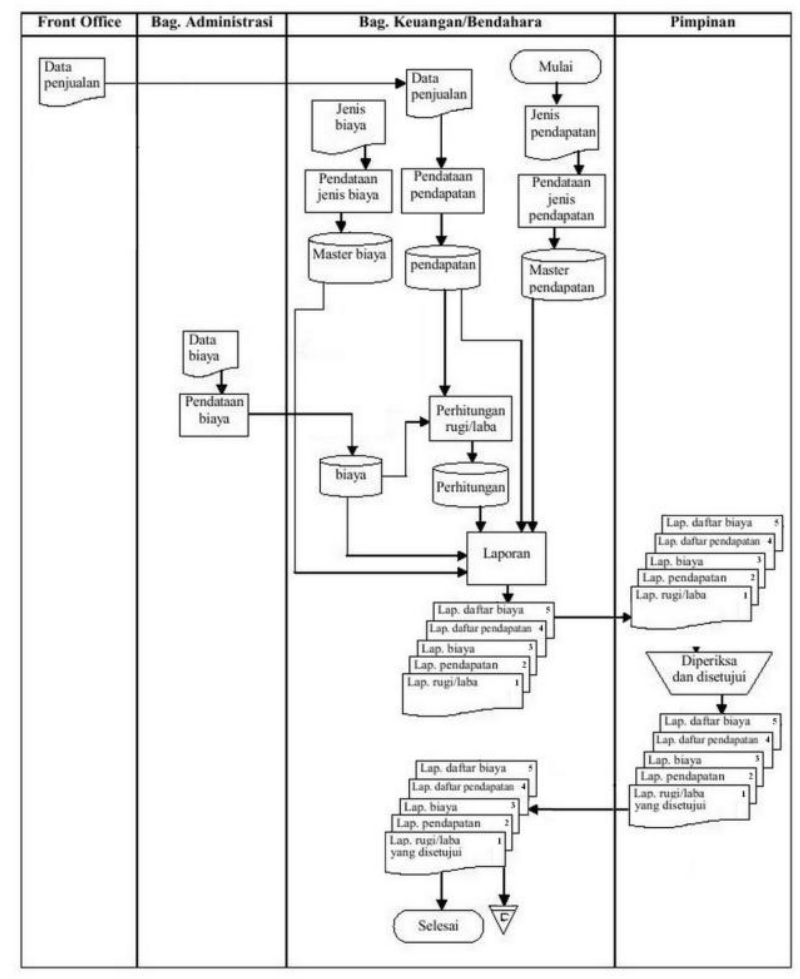

Gambar 3. FOD Sistem Yang Diusulkan

\section{Contex Diagram (CD)}

Pada diagram dibawah terdapat empat buah entitas yaitu entitas front office, bagian administrasi, bagian keuangan atau bendahara dan pimpinan.

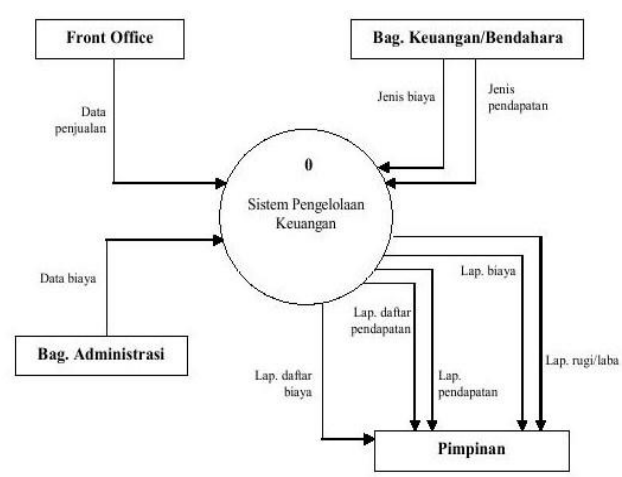

Gambar 4. Contex Diagram

Entitas front office memberikan data penjualan ke sistem. Entitas bagian adminsitrasi memberikan data biaya ke sistem. Entitas bagian keuangan atau bendahara memberikan data jenis pendapatan dan data jenis biaya. Sedangkan entitas pimpinan mendapatkan laporan dari sistem. 


\section{Data Flow Diagram (DFD) Level 0}

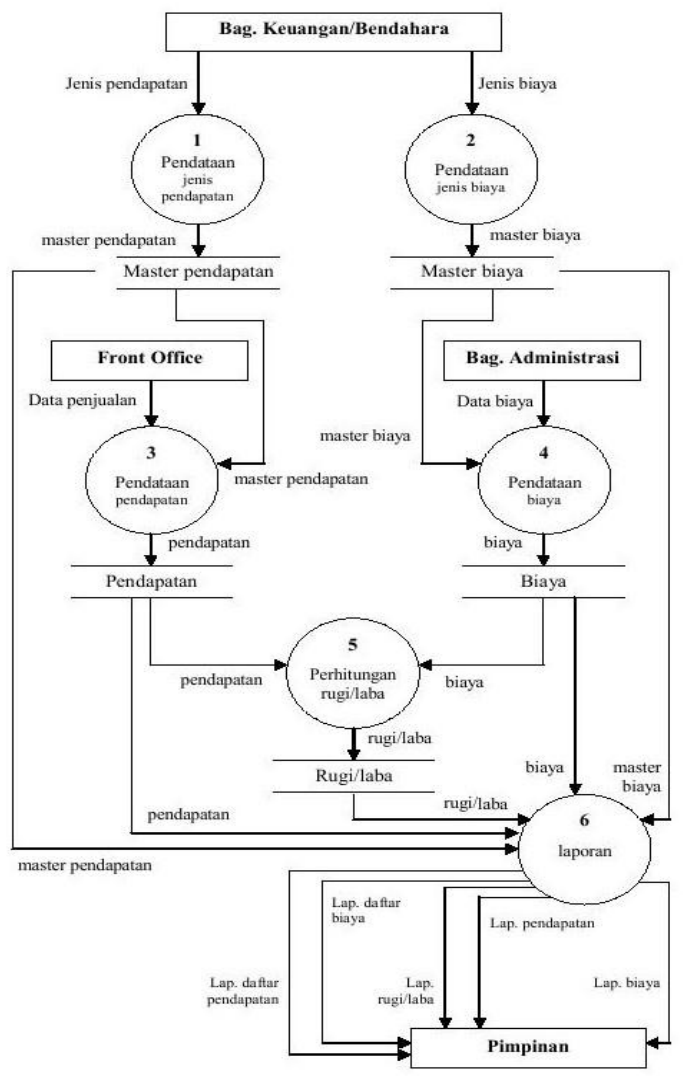

Gambar 5. Data Flow Diagram (DFD) Level 0

Pada Data flow Diagram level 0 tersebut, terdapat empat buah entitas yaitu entitas front office, bagian administrasi, bagian keuangan atau bendahara dan pimpinan. Selain itu, terdapat enam proses yaitu proses pendataan jenis pendapatan, pendataan jenis biaya, pendataan pendapatan, pendataan biaya, perhitungan rugi laba dan proses laporan.

Pada proses pendataan jenis pendapatan, data yang masuk ke sistem yaitu jenis pendapatan dari entitas bagian keuangan atau bendahara. Hasil dari proses tersebut disimpan ke data store master pendapatan. Pada proses pendataan jenis biaya, data yang masuk ke sistem yaitu jenis biaya dari entitas bagian keuangan atau bendahara. Hasil dari proses tersebut disimpan ke data store master biaya.

Pada proses pendataan pendapatan, data yang masuk ke sistem yaitu penjualan dari entitas front office. Hasil dari proses tersebut disimpan ke data store pendapatan. Pada proses pendataan biaya, data yang masuk ke sistem yaitu data biaya dari entitas bagian administrasi. Hasil dari proses tersebut disimpan ke data store biaya. Dari master pendapatan dan master biaya kemudian dilakukan proses perhitungan rugi laba dan hasilnya disimpan di master laba rugi.
Dan pada proses pembuatan laporan, data yang masuk ke dalam sistem yaitu semua dari data store. Laporan yang dihasilkan yaitu laporan daftar pendapatan, laporan daftar biaya, laporan pendapatan, laporan biaya dan laporan laba rugi yang diberikan kepada Pimpinan untuk diperiksa dan disetujui

\section{Data Flow Diagram (DFD) Level 1 Proses Laporan}

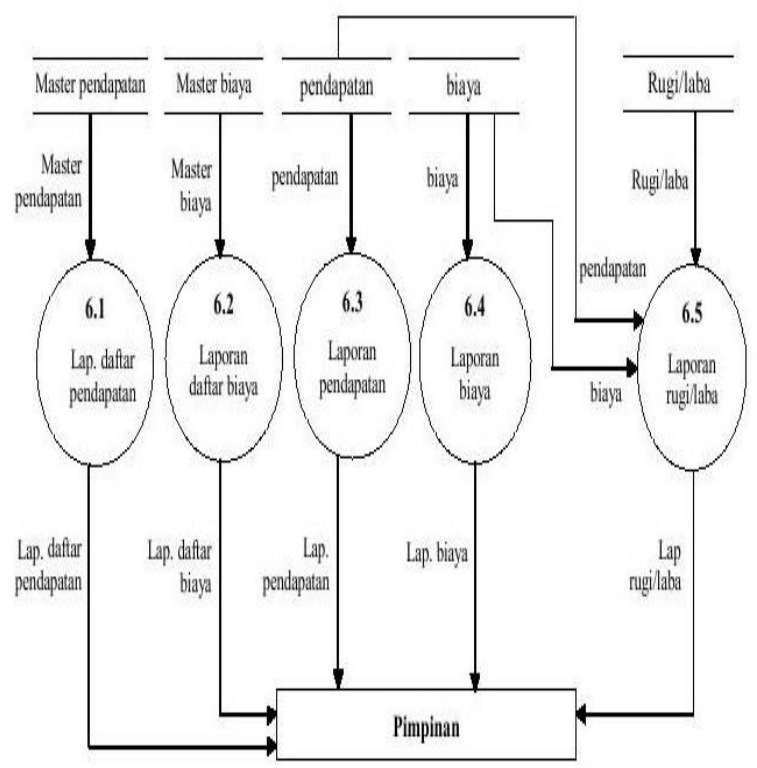

Gambar 6. Data Flow Diagram (DFD) Level 1 Proses Laporan

Pada Data Flow Diagram Level 1 Proses Laporan di atas, terdapat lima proses laporan yaitu proses laporan daftar pendapatan, laporan daftar biaya, laporan pendapatan, laporan biaya dan laporan rugi/laba. Selain itu terdapat lima data store yaitu data store master pendapatan, data store master biaya, data store pendapatan, data store biaya dan data store rugi laba. Laporan yang dihasilkan yaitu laporan daftar pendapatan, laporan daftar biaya, laporan pendapatan, laporan biaya dan laporan rugi/laba yang diberikan kepada Pimpinan untuk diperiksa dan disetujui. 


\section{IMPLEMENTASI}

\section{Tampilan Form Login}

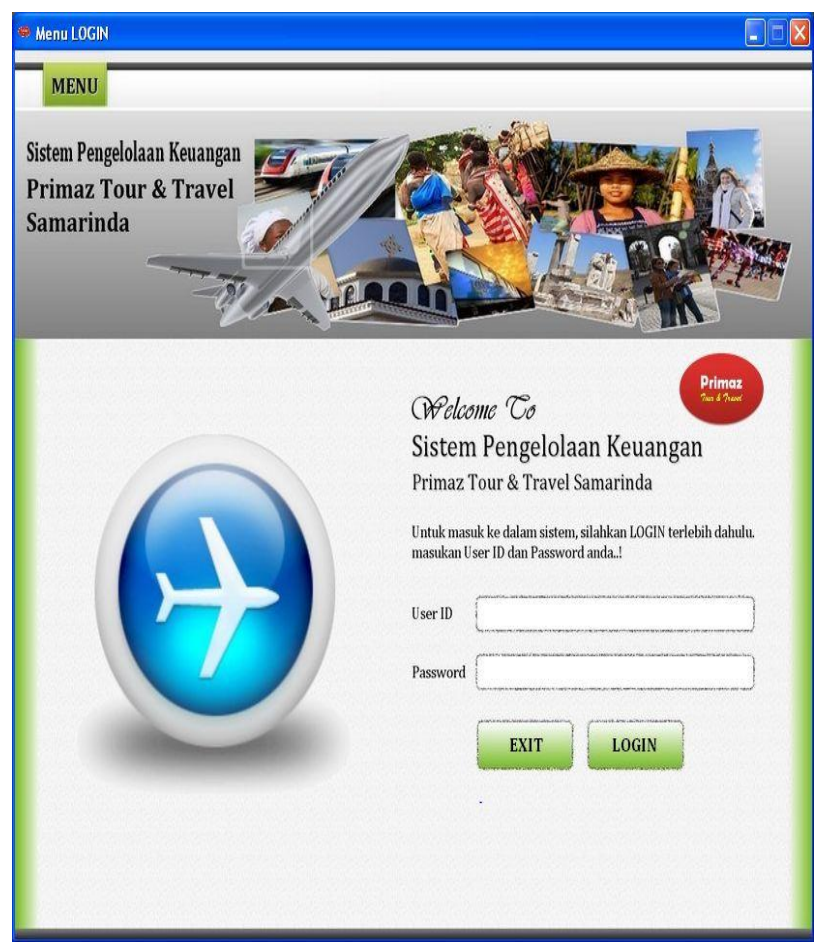

Gambar 7. Tampilan User Login

Seperti pada gambar 7 form login terdiri dari Nama User dan Password yang harus diisi oleh user yang ingin menggunakan sistem ini. Hal tersebut bertujuan agar user yang tidak berhak tidak dapat menggunakan sistem ini. Seteleh user memasukkan Nama dan Password, maka akan diperiksa apakah Nama dan Password tersebut benar atau salah. Jika benar maka user akan masuk ke menu utama dan dapat menggunakan sistem itu.

\section{Tampilan Menu Utama}

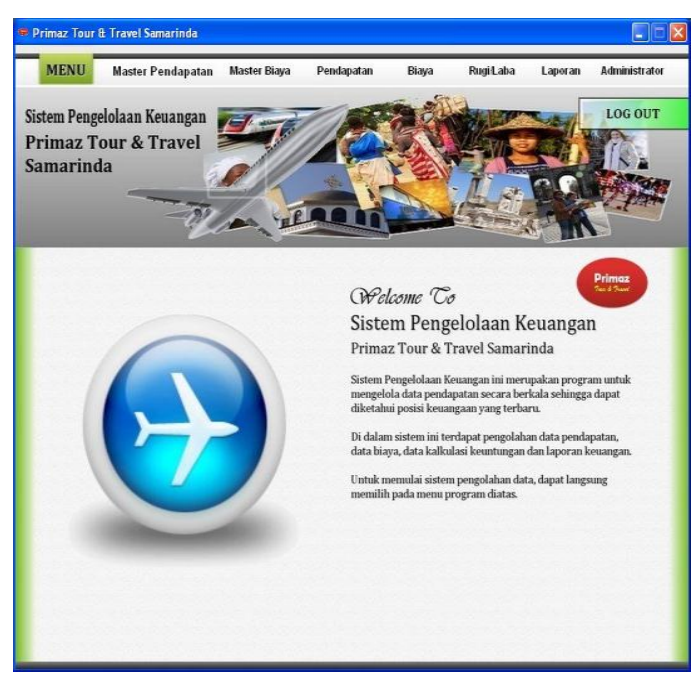

Seperti yang terlihat pada gambar .8 menu utama Sistem Informasi Pengelolaan Keuangan ini terdiri dari tujuh menu yang mempunyai fungsi masing-masing, sebagai sarana dalam pengelolaan keuangan.

\section{Tampilan Master Pendapatan}

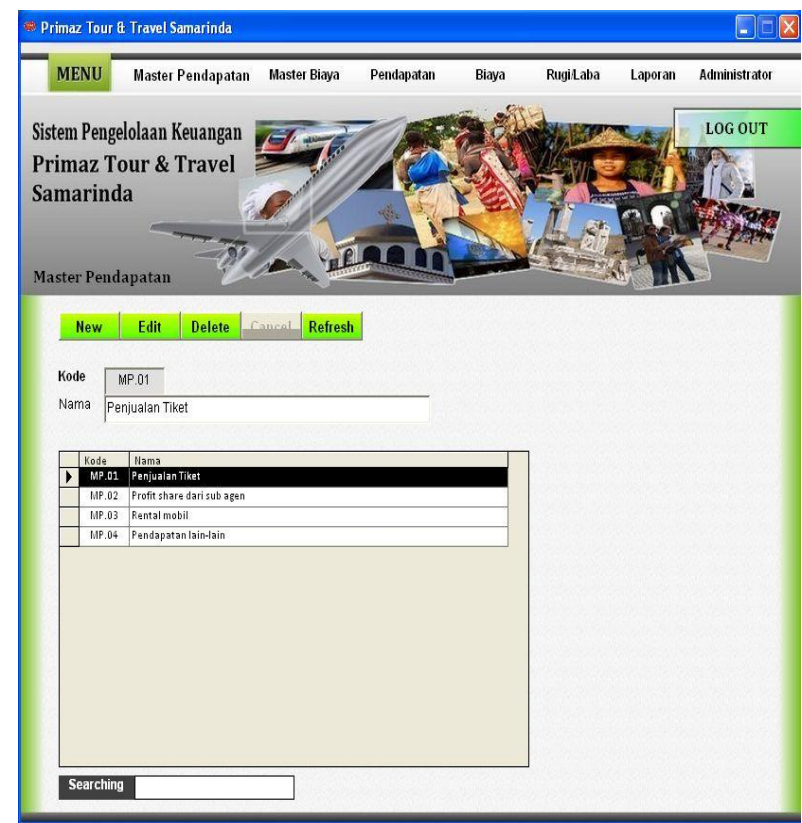

Gambar 9. Tampilan Master Pendapatan

\section{Tampilan Master Biaya}

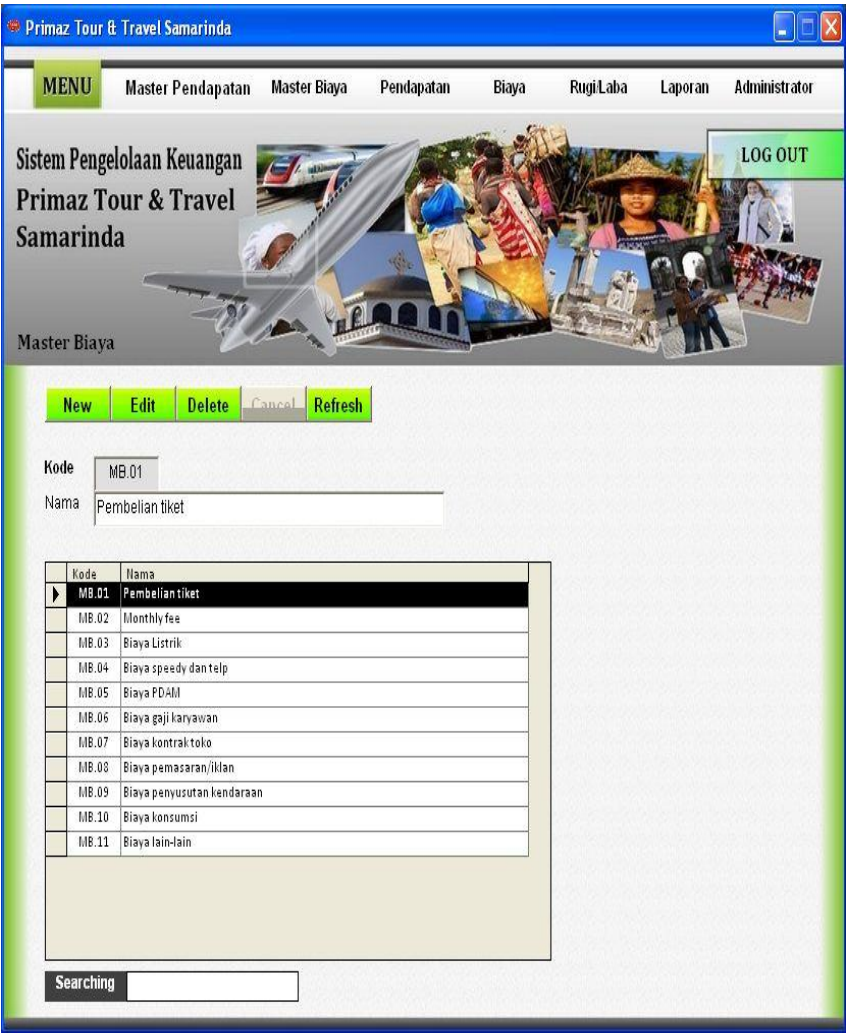

Gambar 10. Tampilan Master Biaya 
Seperti yang terlihat pada gambar 10 form biaya digunakan untuk menginputkan jenis atau macammacam biaya yang akan dikeluarkan untuk kegiatan usaha yang sedang berlangsung.

\section{Tampilan Form Pendapatan}

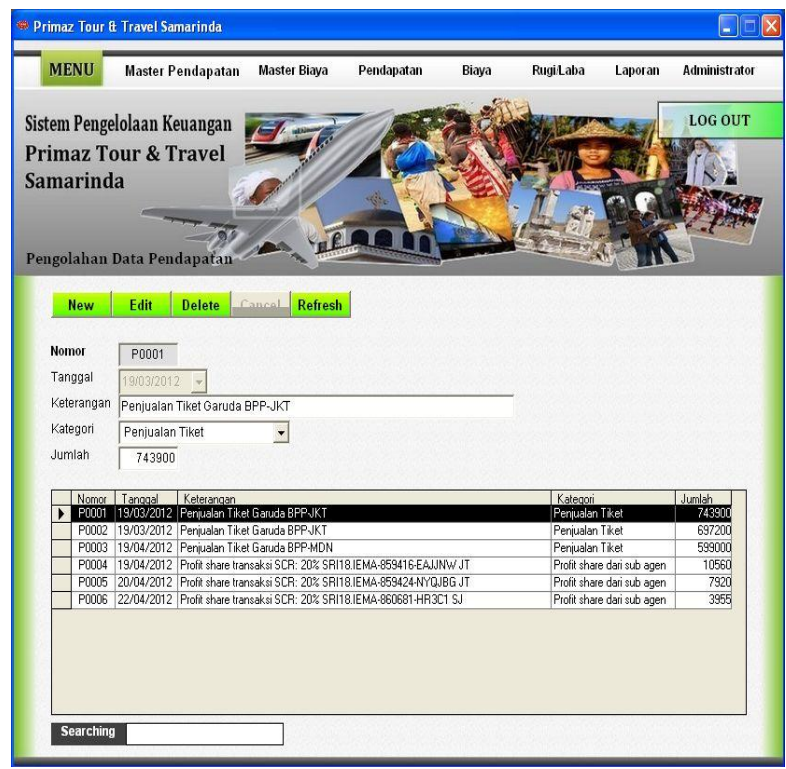

\section{Gambar 11. Tampilan Form Pendapatan}

Seperti yang terlihat pada gambar 11, form pendapatan digunakan untuk menginputkan pendapatan yang telah diterima, baik itu pendapatan dari tiket pesawat, keretaapi, rental mobil, profit share dari sub agen dan pendapatan lain-lain.

\section{Tampilan Form Biaya}

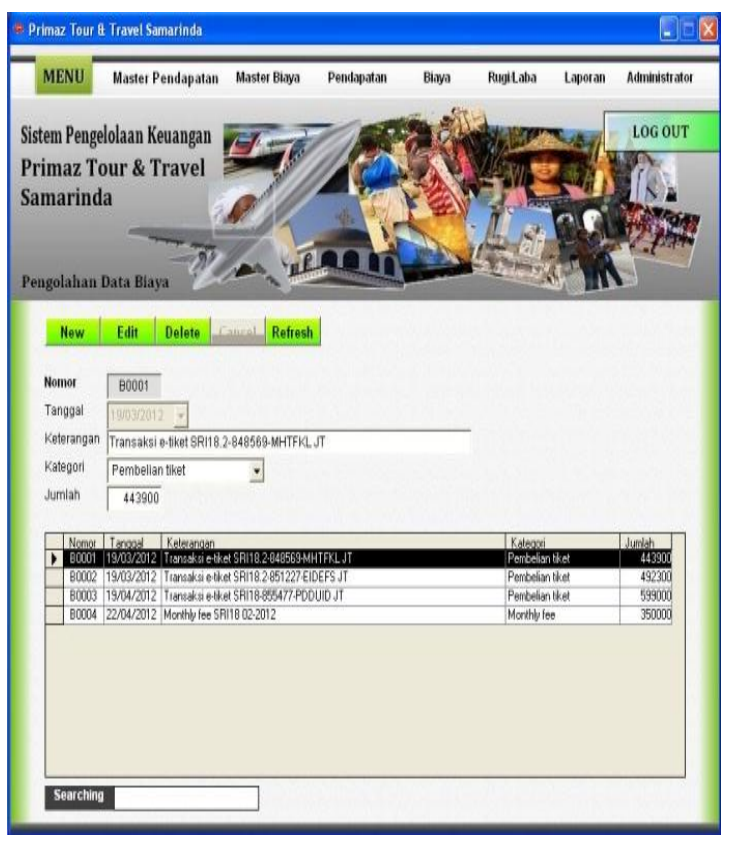

Gambar 12. Tampian Form Biaya
Seperti yang terlihat pada gambar 12 form biaya digunakan untuk menginputkan biaya-biaya yang telah dikeluarkan selama usaha berlangsung.

\section{Tampilan Form Laporan}

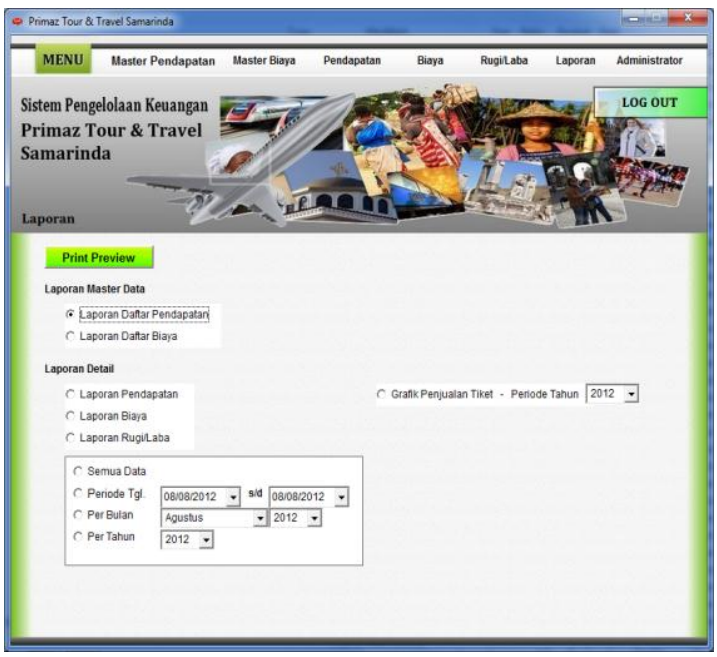

\section{Gambar 13. Tampilan Form Laporan}

Seperti yang terlihat pada gambar 13 form laporan digunakan untuk melakukan perhitungan pendapatan yang telah diterima dan perhitungan biaya yang telah dikeluarkan yang kemudian selanjutnya dipakai sebagai data untuk melakukan perhitungan Rugi/Laba

8. Tampilan Form Perhitungan Rugi/Laba

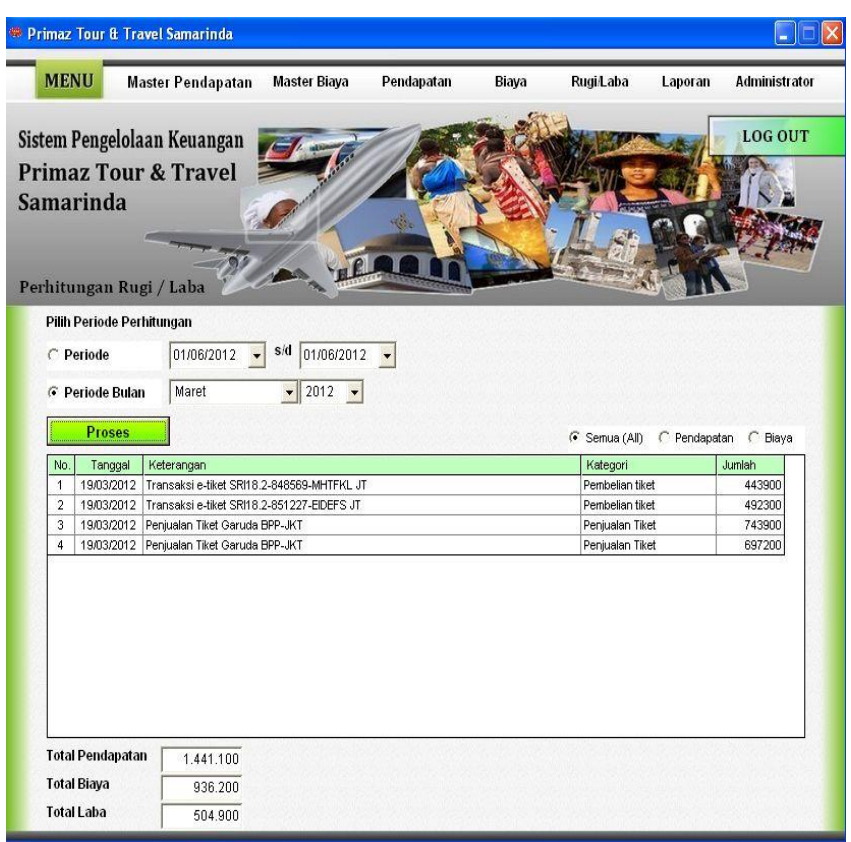

\section{Gambar 14. Form Perhitungan Rugi/Laba}

Seperti yang terlihat pada gambar 14 form laporan rugi/laba digunakan untuk melakukan 
perhitungan rugi/laba, perhitungan ini mengambil data dari perhitungan pendapatan dan perhitungan biaya.

\section{Tampilan Form Administrator}

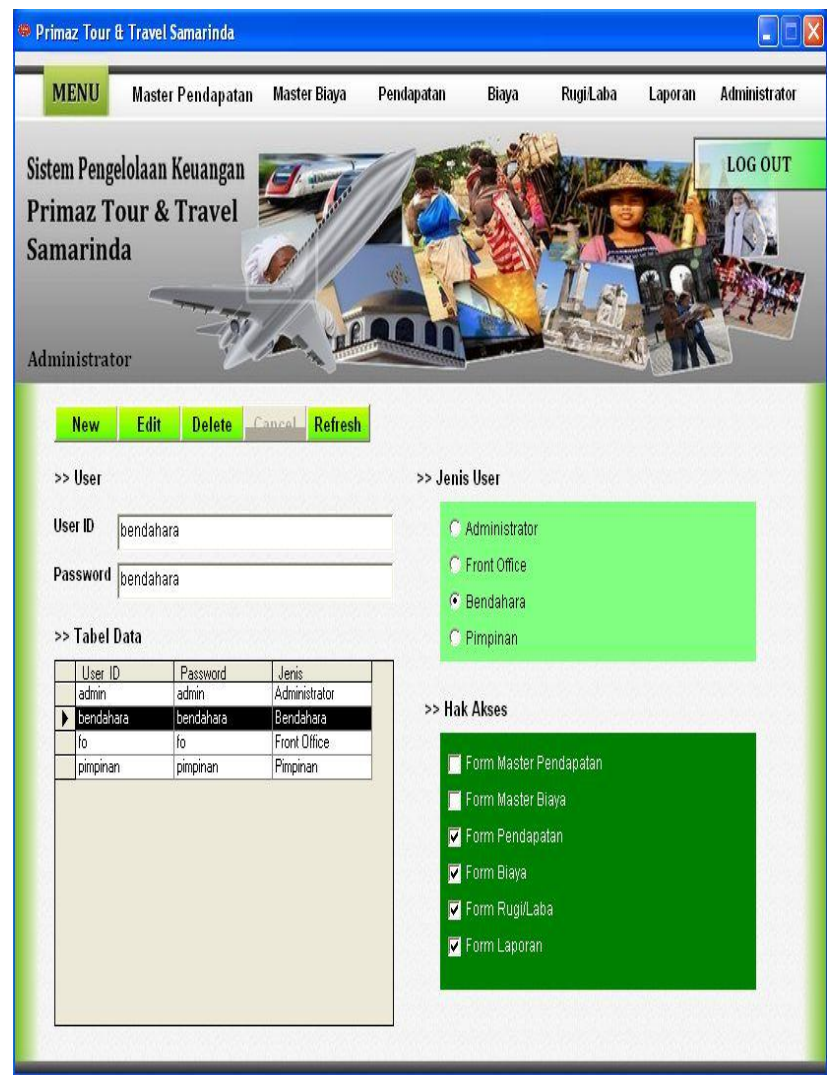

Gambar 15. Tampilan Form 15

Seperti yang terlihat pada gambar 15 form administrator digunakan hak akses untuk membuka dan melihat hasil laporan pengelolaan keuangan yang telah dibuat sehingga dapat memberikan informasi kepada beberapa bagian yang membutuhkannya

\section{Tampilan Output Laporan Master Pendapatan}

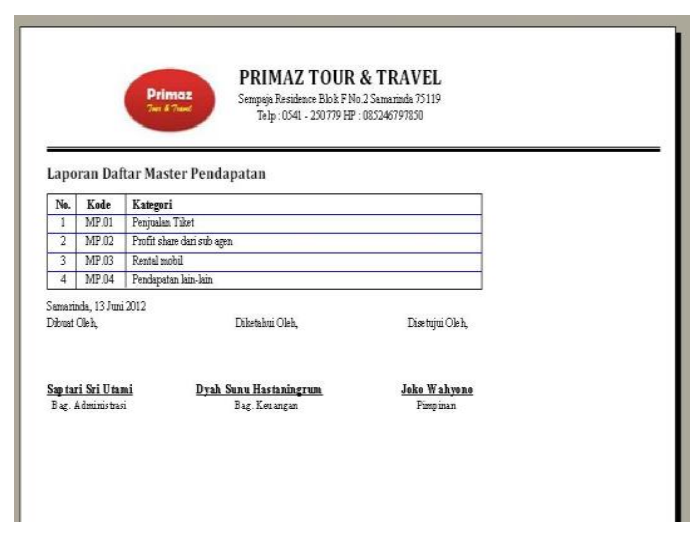

Gambar 16. Output Laporan Master Pendapatan

Berdasarkan gambar 16 laporan master pendapatan digunakan untuk menampilkan jenis-jenis pendapatan kemudian laporan dapat dicetak melalui printer.

\section{Output Master Biaya}

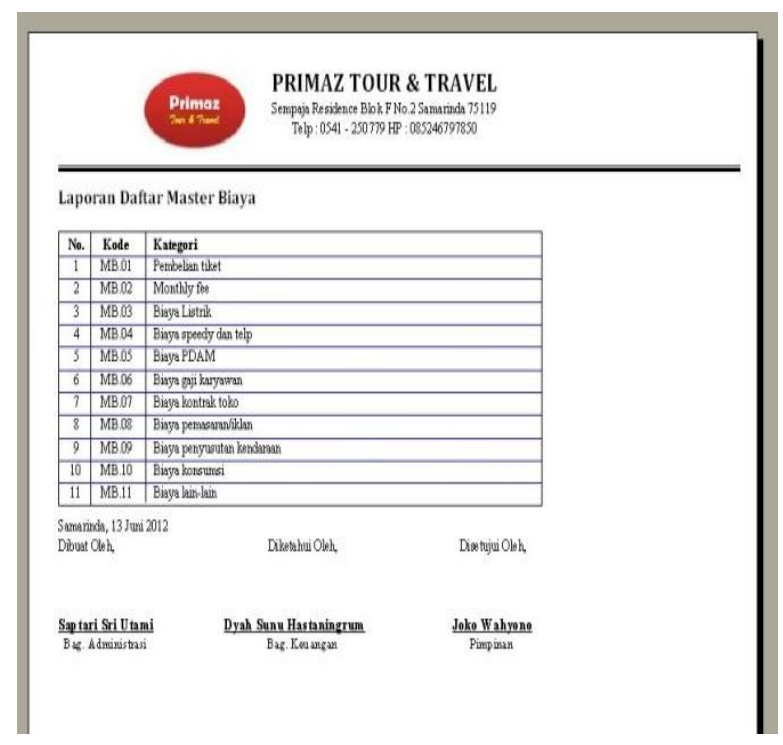

Gambar 17. Output Master Biaya

Berdasarkan gambar 4 2.9.2 laporan master Biaya digunakan untuk menampilkan Jenis-jenis biaya kemudian laporan dapat dicetak melalui printer.

\section{Output Laporan Pendapatan}

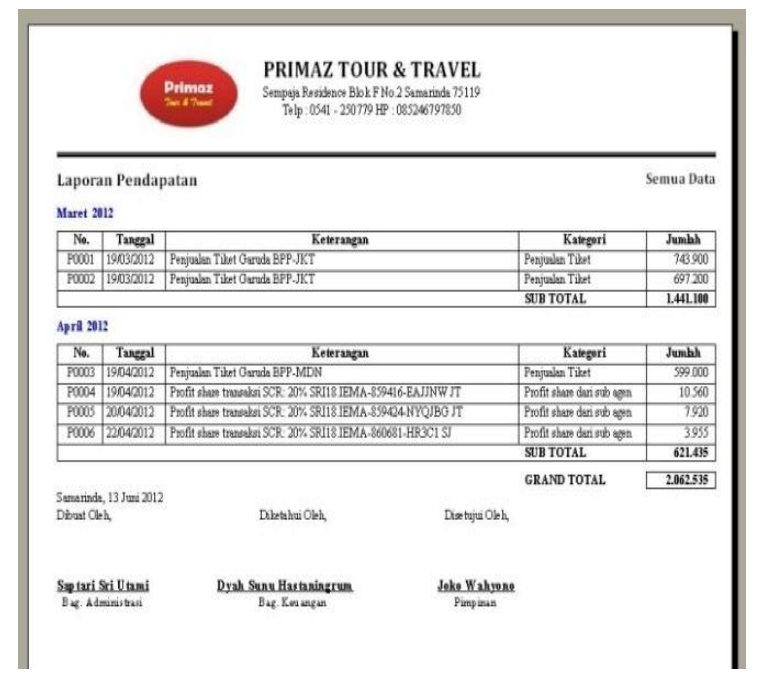

\section{Gambar 18. Laporan Pendapatan}

Berdasarkan gambar 18 output laporan pendapatan digunakan untuk menampilkan Laporan pendapatan yang telah diterima kemudian laporan dapat dicetak melalui printer. 


\section{Output Laporan Biaya}

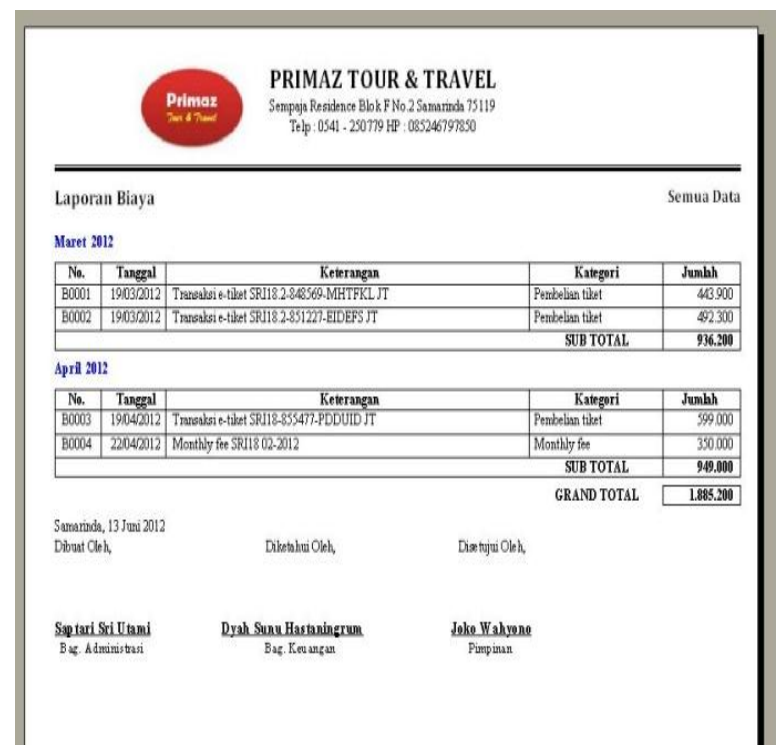

\section{Gambar 19. Output Laporan Biaya}

Berdasarkan gambar 19 output laporan pendapatan digunakan untuk menampilkan laporan biaya yang telah dikeluarkan kemudian laporan dapat dicetak melalui printer

\section{Output Laporan Rugi/Laba}

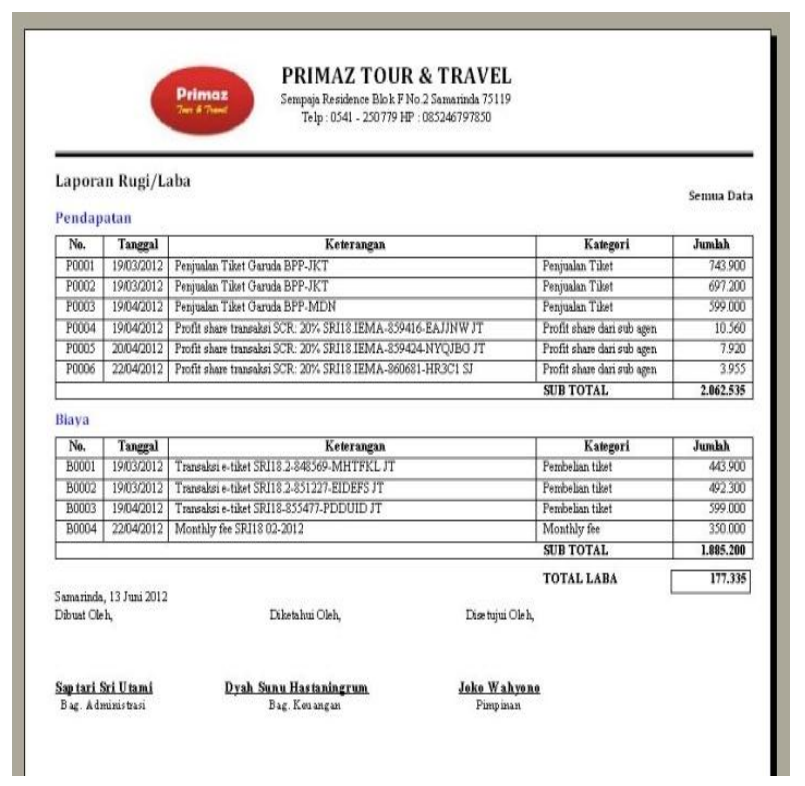

Gambar 20. Output Laporan Rugi/Laba

Berdasarkan gambar 20output laporan rugi/laba digunakan untuk menampilkan perhitungan laporan rugi/laba , yang kemudian laporan dapat dicetak melalui printer

\section{Output Grafik Penjualan Tiket}

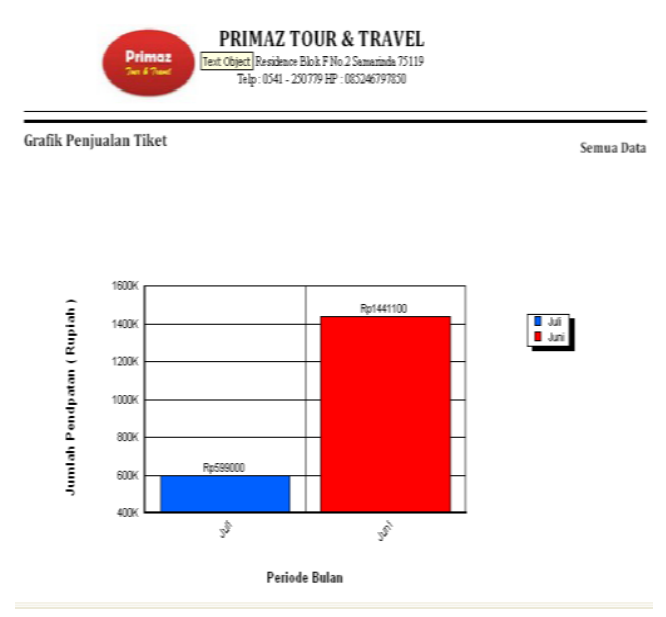

Gambar 21.Grafik Penjualan Tiket

Berdasarkan gambar 21 output Grafik penjualan tiket, yang kemudian laporan dapat dicetak melalui printer, diambil dari sample input pendapatan tiket bulan Juni dan Juli 2012.

\section{KESIMPULAN}

Dari hasil penelitian dan pembahasan yang dilakukan, maka dapat ditarik kesimpulan sebagai berikut :

1. Sistem Pengelolaan Keuangan Berbasis LAN ini dapat membantu Pimpinan memperoleh data laporan keuangan secara periodik.

2. Sistem ini secara otomatis memberi peringatan kepada user jika terdapat data inputan yang tidak lengkap seperti data penjualan, pembelian dan biaya

3. Sistem ini dapat menampilkan laporan keuangan berupa Laporan Pendapatan dan Biaya atau Laporan Rugi/Laba.

\section{SARAN}

Berdasarkan dari hasil penelitian ini, penulis menyarankan sebagai berikut :

1. Aplikasi Pengelolaan Keuangan berbasis LAN ini tentunya masih terdapat banyak kekurangan. Oleh karena itu aplikasi ini masih dapat dikembangkan menjadi aplikasi berbasis web. Sehingga User dapat menggunakan kapan saja dan tidak dibatasi waktu dan tempat.

2. Disarankan kepada Primaz Tour \& Travel agar lebih banyak menggunakan komputer aplikasi ini untuk membantu pekerjaan administrasi dan keuangan agar dapat membantu pimpinan dalam kelancaran proses operasional perusahaan.

3. Dalam menginput data penjualan, pembelian dan biaya, user harus dibekali keterampilan akuntansi dasar, agar tidak terjadi kesalahan yang tidak diinginkan 


\section{DAFTAR PUSTAKA}

Departemen Pendidikan Nasional, 2002, Кamus Lengkap Bahasa Indonesia, edisi kedua, Penerbit Balai Pustaka, Jakarta

Jogiyanto, HM, 2008, Analisis dan Desain Sistem Informasi Edisi Ketiga, Cetakan Kedua, Yogyakarta : Andi Offset.

Kadir, Abdul, 2007, Konsep dan Tuntunan Praktis Basis Data, Yogyakarta: Andi Offset.

Kadir, Abdul, 2009, Mudah Mempelajari Database Mysql, Yogyakarta: Andi Offset.

Kristanto, Andi, 2003, Perancangan Sistem Informasi dan Aplikasinya, Yogyakarta : Gava Media.

Putra, Roni (2008) Implementasi Sistem Informasi Akademik Berbasis LAN (Studi Kasus pada Jurusan Teknologi Informasi Politeknik Universitas Andalas). Other thesis, Politeknik Universitas Andalas.

Rafiudin, Rahmat, 2003. Panduan Pembangunan Jaringan Komputer Untuk Pemula, Jakarta : PT. Elex Media Komputindo

Simarmata, Janner, 2010, Perancangan Basis Data Edisi ke-1,Yogyakarta : Andi Offset

Subari \& Yuswanto, 2008, Penduang Lengkap Pemograman Visual Basic 6.0, Jakarta : Cerdas Pustaka Publisher.

Supriyanto, Aji, 2005. Pengantar Teknologi Informasi, Semarang : Salemba Infotek.

Scott, George M., 2002, Prinsip-prinsip Sistem Informasi Manajemen, Cetakan Keenam, Jakarta : PT. Raja Grafindo Persada.

Supriyanto, Aji, 2005, Pengantar Teknologi Informasi, Semarang : Salemba Infotek.

Yuswanto, 2003, Pemrograman Dasar Microsoft Visual Basic 6.0, Surabaya : Prestasi Pustaka. 